\title{
Optimization of The Utilization Of The Road Health Services in The General Hospital of Kertha Usada, Singaraja, 2019
}

\author{
I Gede Budayana \\ Magister of Public Health Program of \\ Institut Ilmu Kesehatan STRADA \\ Indonesia \\ Email: \\ budayana33@gmail.com
}

Received: October 12, 2019

Accepted : February 13, 2020

Published : May 12, 2020

\section{ABSTRACT}

The research design used was a quantitative study using an observational approach with a cross sectional study design that is data collection that would be measured only once and without any treatment to 272 respondents. Data analysis techniques using descriptive analysis and linear logistic regression test. The results showed that the community characteristics of the 272 respondents studied, based on predisposing factors, amounted to $54.8 \%$ aged 26-45 years, $57 \%$ female sex with the most undergraduate education by $32 \%$ and the most work did not work $27 \%$. As many as $77.9 \%$ of respondents felt confident.

Based on the enabling factors, most respondents (69\%) earn> Rp. 1,800.00 - and all have health insurance (BPJS), with the largest distance $>5 \mathrm{~km}$ of $58.1 \%$ and the most frequent family treatment habits to the hospital that is $46.7 \%$. Based on the factor of need for illness, the majority of respondents $61 \%$ had complaints of pain in the low category and the severity of pain in the severe category of 51.5\%. The level, patient satisfaction at the Kertha Usada Hospital based on the results of the study amounted to $68.4 \%$ with a good category.

The results of linear regression analysis between community characteristics and patient satisfaction with the utilization of health services stated that the variables of age, sex and patient satisfaction have an influence on the utilization of health services. Whereas based on the results of statistical analysis using a linear logistic regression test showed that the value of the Omnibus Test was 75,246 on (Chi-square) with a significance of $0,0005(<0.05)$ so that it refused $\mathrm{H} 0$ and accepted $\mathrm{H} 1$, which showed that it could have a real influence on the model which is used, or in other words the model is declared FIT. Optimizing the utilization of health services affects the service system, the factors that affect service and patient satisfaction in hospitals

Keywords: Hospital Optimization, Patient Satisfaction, Utilization Of Health Services 


\section{INTRODUCTION}

The hospital as an institution engaged in the field of health services underwent a change, at the beginning of its development, the hospital was an institution that functioned socially, but with the existence of a private hospital, it made the hospital more referring to as an industry engaged in the field of health services by carrying out effective management. based on business entity management. Along with that, there was competition between fellow hospitals both government-owned hospitals and private-owned hospitals, all competing to attract consumers to use their services. At present, the hospital is developing as a labor intensive, capital intensive and technology intensive industry. So called because the hospital utilizes Human Resources (HR) in large numbers and various qualifications. Likewise, the amount of funds used to carry out various types of services, including hospital revenue. Hospitals also utilize various types of cutting-edge medical technology to improve the quality of their services. The general product of the hospital industry is health services (Muninjaya, 2011).

Kertha Usada General Hospital is a class C hospital which also works closely with the BPJS and has 144 beds. The location of Kertha Usada Hospital is very strategic because it is located in the city center. Based on outpatient visit data at Kertha Usada General Hospital, Singaraja from 2015 to 2018 there was a decrease in visits. In 2016-2017 there was a decrease in visits by $18.89 \%$ while in 20172018 there was an increase of $0.02 \%$. This may be due to government policies or lack of use of services by the community and other factors.

A preliminary survey was conducted on patients who had used the services of the Kertha Usada General Hospital outpatient unit. The questionnaire used was a RATER questionnaire from Groonros. It aims to look for things that cause a decrease in visits to the outpatient unit of Kertha Usada Hospital. The following are the results of a survey in the outpatient unit of Kertha Usada Singaraja Hospital.

Based on the results of a preliminary study at Kertha Usada General Hospital through a questionnaire of 30 outpatients, the results showed that the average patient satisfaction was at a value of $65.55 \%$ where this number had not reached the standards set by the Ministry of Health. Decreased patient satisfaction will affect the number of patient visits and have an impact on the quality of service from outpatients in the Kertha Usada Singaraja Hospital.

Based on these data the problem statement in this study was the decrease in patient visits in 20162017 by $18.89 \%$ and the low patient satisfaction in 2018 which was $65.55 \%$ in the outpatient unit of Kertha Usadha Hospital.

\section{METHODS}

This research uses an observational approach with a cross sectional study design with a sample of 272 patients who use outpatient health services / erderly with Proportional Cluster Sampling. The independent variable (community characteristics, patient satisfaction) to the dependent variable (frequency of utilization of health services) using a questionnaire at Kertha Usada General Hospital, Singaraja in November 2019. Data were processed and analyzed by linear logistic regression test.

\section{RESULTS}

\section{Descriptive Public Data}

Table 1 Distribution of respondent characteristics based on predisposing factors at Kertha Usada General Hospital, Singaraja 2019.

\begin{tabular}{clcc}
\hline No & characteristic & $(\mathrm{f})$ & $(\%)$ \\
\hline 1 & $0-11$ years & 46 & 16,9 \\
\hline 2 & 12-25 years & 44 & 16,2 \\
\hline 3 & $26-45$ years & 149 & 54,8 \\
\hline 4 & $>45$ years & 33 & 12,1 \\
\hline & Total & 272 & 100.0 \\
\hline 1 & Male & 117 & 43 \\
\hline 2 & Female & 155 & 57 \\
\hline & Total & 272 & 100.0 \\
\hline 1 & Does not work & 76 & 27.9 \\
\hline 2 & Labor & 13 & 4.8 \\
\hline
\end{tabular}




\begin{tabular}{clcc}
\hline 3 & Private employees & 70 & 25.7 \\
\hline 4 & Regional Contract Workes & 9 & 3.3 \\
\hline 5 & Civil Servants & 74 & 27.2 \\
\hline 6 & Entrepreneur & 25 & 9.2 \\
\hline 7 & Army/Police & 5 & 1.8 \\
\hline & Total & 272 & 100.0 \\
\hline 1 & Sure & 212 & 77.9 \\
\hline 2 & Not sure & 60 & 22.1 \\
\hline & Total & 272 & 100.0 \\
\hline
\end{tabular}

Source : Primary Data (2019)

Based on table 1 it can be seen that the majority of respondents who use outpatient health services by age group 26-45 years (54.8\%), most are female (57\%), based on work most are not working $(27.9 \%)$ and most felt confident about health services $(77.9 \%)$.

Table 2 Distribution of respondent characteristics based on enabling factors at Kertha Usada General Hospital, Singaraja 2019.

\begin{tabular}{clcc}
\hline No & characteristic & $(\mathrm{f})$ & $(\%)$ \\
\hline 1 & $\leq$ Rp. 1.800 .000 & 83 & 31 \\
\hline 2 & $>$ Rp. 1.800 .000 & 189 & 69 \\
\hline & Total & 272 & 100.0 \\
\hline 1 & Have BPJS & 272 & 100.0 \\
\hline 2 & Does not have BPJS & 0 & 0 \\
\hline & Total & 272 & 100.0 \\
\hline 1 & $<2.5 \mathrm{Km}$ & 44 & 16.2 \\
\hline 2 & $2.5 \mathrm{Km}-5 \mathrm{Km}$ & 70 & 26 \\
\hline 3 & $>5 \mathrm{Km}$ & 158 & 58.1 \\
\hline & Total & 272 & 100.0 \\
\hline 1 & To the hospital & 127 & 46.7 \\
\hline 2 & To the family doctor & 5 & 1.8 \\
\hline 3 & Just ignore it & 4 & 1.5 \\
\hline 4 & Treated alone & 29 & 10.7 \\
\hline 5 & To the Puskesmas & 107 & 39.3 \\
\hline & Total & 272 & 100.0 \\
\hline
\end{tabular}

Based on table 2 it can be seen that the majority of respondents who use outpatient health services based on income are mostly> Rp. 1,800,000 (69\%), and all respondents have BPJS health insurance $(100 \%)$, based on the most distance> $5 \mathrm{~km}(58.1 \%)$ and based on medical treatment habits, most of them have the habit of going to the hospital $(46,7 \%)$

Table 3 Distribution of respondent characteristics based on the factor of need for illness in Kertha Usada General Hospital, Singaraja 2019.

\begin{tabular}{clcc}
\hline No & characteristic & $(\mathrm{f})$ & $(\%)$ \\
\hline 1 & High & 106 & 39 \\
\hline 2 & Low & 166 & 61 \\
\hline & Total & 272 & 100.0 \\
\hline 1 & Severe & 132 & 48.5 \\
\hline 2 & Not severe & 140 & 51.5 \\
\hline & Total & 272 & 100.0 \\
\hline
\end{tabular}


Based on table 3, it can be seen that the majority of respondents who use outpatient health services based on pain complaints are mostly low (61\%) and based on the severity of pain, most are not severe $(51.5 \%)$

Table 4 Distribution of respondent characteristics based on patient satisfaction at Kertha Usada General Hospital, Singaraja 2019.

\begin{tabular}{clcc}
\hline No & characteristic & $(\mathrm{f})$ & $(\%)$ \\
\hline 1 & Good & 186 & 68.4 \\
\hline 2 & Ugly & 86 & 31.6 \\
\hline & Total & 272 & 100.0 \\
\hline
\end{tabular}

Based on table 4 it can be seen that respondents who use outpatient health services based on patient satisfaction are mostly good $(68.4 \%)$

Table 5 Distribution of respondent characteristics based on utilization of outpatient health services at Kertha Usada General Hospital, Singaraja 2019

\begin{tabular}{clcc}
\hline No & characteristic & $(\mathrm{f})$ & $(\%)$ \\
\hline 1 & High & 145 & 53.3 \\
\hline 2 & Low & 126 & 46.3 \\
\hline & Total & 272 & 100.0 \\
\hline
\end{tabular}

Based on table 5 it can be seen that respondents who use outpatient health services based on utilization of outpatient health services are mostly high (53.3\%)

\section{Data analysis}

Table 6 Analysis of Linear Regression Test Predisposing Factors, Enabling Factors, Factors of Pain Needs and Patient Satisfaction with Utilization of Health Services in the Outpatient Unit of Kertha Usada Hospital, Singaraja 2019.

\begin{tabular}{clcc}
\hline No & \multicolumn{1}{c}{ Variable } & Sig & Information \\
\hline & Predisposing factors & & \\
\hline 1 & Age & 0,032 & Significant \\
\hline 2 & Gender & 0,039 & Significant \\
\hline 3 & Education & 0,289 & Not significant \\
\hline 4 & Profession & 0,746 & Not significant \\
\hline 5 & Confidence & 0,180 & Not significant \\
\hline & Enabling Factor & & Not significant \\
\hline 1 & Income & 0,266 & Not significant \\
\hline 2 & Distance & 0,400 & \\
\hline 3 & Family Medication Habits & 0,053 & Not significant \\
\hline & Pain Requirement Factor & & Not significant \\
\hline 1 & Complaint & 0,682 & Significant \\
\hline 2 & Severity & 0,258 & 0,000 \\
\hline 1 & Patient Satisfaction & &
\end{tabular}

Source : Primary Data (2019)

Based on table 6 above it can be seen that the variables of age, sex and patient satisfaction have a significance number $p>0.05$. This can be interpreted that the age, gender and patient satisfaction variables have an influence on the utilization of outpatient health services 
Linear Logistics Analysis

Table 7 Linear Logistics Analysis of Community Characteristics and Patient Satisfaction with Utilization of Health Services

\begin{tabular}{l|l|c|c|c}
\hline \multicolumn{5}{c}{ Omnibus Tests of Model Coefficients } \\
\hline \multirow{3}{*}{ Step 1 } & & Chi-square & df & Sig. \\
\cline { 2 - 5 } & Step & 75.246 & 9 & .000 \\
\cline { 2 - 5 } & Block & 75.246 & 9 & .000 \\
\cline { 2 - 5 } & Model & 75.246 & 9 & .000 \\
\hline
\end{tabular}

Based on table 7 above it can be explained that the analysis of Linear logistic data shows the results of the Omnibus Test value of 75,246 on (Chi-square) with a significance of $0,0005(<0.05)$ so that it rejects $\mathrm{H0}$, which shows that it can have a real influence on the model used, or in other words, the model is declared FIT

\section{DISCUSSION \\ Identification of Community Characteristics based on Predisposing Factors utilizing Outpatient Health Services at Kertha Usada General Hospital, Singaraja 2019}

Community characteristics of the frequency of Outpatient Health Services Utilization at Kertha Usada General Hospital based on predisposing factors namely age, sex, education, occupation and belief. The description of the community based on the age group most of the respondents who use health services are the 26-45 year age group that is $54.8 \%$ of 272 respondents. In life, every human being knows the needs and desires, the difference between the needs and desires is the level of age (Nitisusastro, 2012).

Gender-based figures are 155 respondents (57\%) and 117 respondents (43\%) men. According to (Muriithi, 2013) explained that men have a small possibility of not using or utilizing health services compared to a woman.

Distribution based on education, most of the respondents are bachelor (32\%), then high school / equivalent (23.9\%) and the lowest is junior high / equivalent. Educational status is closely related to one's awareness and knowledge, so that educational status has a significant influence on the utilization of health services. Usually people who have low education, lack awareness and good knowledge about the benefits of health services (Rumengan, Umboh, \& Kandou, 2015).

Work-based distribution shows that the majority of respondents who use outpatient health services at Kertha Usada General Hospital are unemployed (27.9\%). A person's work also affects their consumption patterns. Thus, the types of work have a very broad and very diverse influence on consumer behavior (Nitisusastro, 2012). From the results of research that do not work more use, this may be caused by respondents who do not work more free time than those who work in terms of utilization of health services.

Based on the confidence of the majority of respondents who use health services feel confident that as many as 212 respondents $(77.9 \%)$. Beliefs are related to interactions between officers and patients. One of the factors that influence the utilization of health services is the level of confidence in the health services provided. A good relationship instills trust and credibility by valuing what can be seen through acceptance, trust, empathy, keeping secrets, respecting and giving attention to patients.

\section{Identification of Community Characteristics based on Enabling Factors utilizing Outpatient Health Services at Kertha Usada General Hospital, Singaraja 2019}

Enabling factors that are identified are income, ownership of health insurance, distance and family treatment habits. Community-based distribution of income shows that respondents who use health services most earn> Rp. 1800,000, - 189 respondents (69\%). Product choices are strongly influenced by economic conditions. Spending income, savings and assets, debt, loan strength, and attitudes toward spending and savings.

Of the 272 respondents, all of them already have health insurance, namely BPJS. The national health insurance program or currently better known as the National Health Insurance (JKN), can 
increase access to health services. This shows that health insurance has a positive impact on access to health services in the community.

Based on the distance most of the respondents who use health services are respondents who have a distance of $>5 \mathrm{~km}$ as many as 158 respondents $(58.1 \%)$. Distance is one of the important factors for the community to utilize health services. Respondents who are far away actually use more health services than those who are close because this is respondents who live far away are more enthusiastic, so that this becomes a motivating factor for checking their health in the health service compared to respondents whose dwelling is located close they assume that where health services are easy to reach, so they delay checking their health and eventually they become lazy to visit health services.

Judging from the habit of family treatment, most respondents had the habit of going to the hospital as many as 127 respondents $(46.7 \%)$. Tradition is a hereditary habit of a group of people based on the cultural values of the people concerned. Tradition shows how members of society behave both in worldly life and in matters that are supernatural or religious.

\section{Identification of Community Characteristics based on Pain Needs utilizing Outpatient Health Services at Kertha Usada General Hospital, Singaraja 2019}

Community identification is based on the factor of need for pain based on the factors of pain complaints and pain severity. Based on illness complaints, most respondents had low pain complaints with 166 respondents (61\%). Nadjib uses the number of illness complaints as a proxy for a person's need for health services (Nadjib, 1999 in Su'udi, 2010). According to the Health Service Use theory from Andersen (1975) states that people's behavior in utilizing health services is determined by the level or degree of illness experienced and the need for health services (perceived need).

Distribution based on the severity of illness most of the respondents who use health services in the category of not severe as many as 140 respondents $(51.5 \%)$. The severity of the perceived illness causes the individual to believe that the consequences of the perceived severity are a threat to his life. So that individuals will take action to seek treatment and prevention of disease (Sholiha, 2014).

The level or degree of disease that is increasingly felt severe, then the individual will increasingly need healing so that the need for health services will be increasingly similar to the need for health services, if the higher the need for a service, the higher will the desire to use health services the

\section{Identification of Patient Satisfaction Using Outpatient Health Services At Kertha Usada General Hospital, Singaraja 2019}

The level of patient satisfaction at Kertha Usada General Hospital is assessed based on 5 service dimensions, namely Reliability / Trustworthiness, Assurance / Tangibles / Direct Evidence, Emphaty / Care, and Responsiveness / Responsiveness. Outpatient satisfaction at Kertha Usada General Hospital, Singaraja at $68.4 \%$ stated good, while the remaining 31.6\% stated poor. Based on Kepmenkes No. 129 / Menkes / SK / II / 2008 that outpatient customer satisfaction is at least\% 90\%. This means that the level of patient satisfaction at Kertha Usada General Hospital, Singaraja is still below the established standards. This of course will have an impact on the utilization of health services. If the patient feels satisfied with the services provided, then the patient will use the health service again in accordance with his experience

\section{Identification of Factors for Using Outpatient Health Services at Kertha Usada General Hospital, Singaraja 2019}

Based on the results of the study showed that as many as 145 respondents $(53.3 \%)$ had high utilization and the remaining 126 respondents (46.3\%) with low categories. According to Feldstein (1983) in Suriati (2009), that in the health sector the analysis of the utilization of health services is useful for knowing the pattern of utilization (use) of health services by the community. This information is useful as input for decision makers to plan and manage health services to be more effective and efficient. 


\section{Analysis of the Influence of Community Characteristics and Patient Satisfaction on Utilization of Health Services}

Based on the results of the linear regression test variables that affect the utilization of outpatient health services at Kertha Usada General Hospital, Singaraja are variables of age, gender and patient satisfaction, where the significant value is $\mathrm{p}<0.05$. Age according to research (Cheruvu \& Oancea, 2016) age plays a role in the utilization of health services. The gender variable also influences, because women have a greater degree of concern than men who are slightly less concerned so women pay more attention to health conditions by going to health services when sick.

Analysis of the influence of community characteristics and patient satisfaction on the use of health services can be tested with the Linear Logistics Test. The hypothesis that refers to this study is strongly supported because the Logistic Regression Test value is significant $p=0.0005(<0.05)$ so that it accepts $\mathrm{H} 1$, which shows that the model can be accepted and hypothesis testing can be done because there is a significant difference between the model and its observation value.

\section{CONCLUSION}

The description of community characteristics based on predisposing factors that utilize health services in Kertha Usada Hospital is mostly aged $36-45$ years at $54.8 \%$, with female sex at $57 \%$. Based on the education of most scholars, $32 \%$. Based on work that utilizes health services, most of them do not work (27.9\%), and based on belief in using health services in Kertha Usada General Hospital, 77.9\%.

The description of the community is based on the enabling factors that make use of health services when viewed from the majority of income earners $>1,800,000(69 \%)$. All respondents have health insurance. When viewed from a distance, most respondents have a distance of $>5 \mathrm{Km}(58.1 \%)$. Based on the habits of family treatment, most of the people stated that they used the health center (46.7\%).

The community picture based on complaints of illness is mostly in the low category $61 \%$ and based on the severity of the pain most are categorized as not severe that is equal to $51.5 \%$.

Patient satisfaction using outpatient health services at RSU Kertha Usada with a good category of $68.4 \%$.

The description of the utilization of health services in Kertha Usada General Hospital, Singaraja with a high category of $53.3 \%$.

Based on a linear regression test the variables of age, gender and patient satisfaction have an influence on the utilization of health services. Whereas based on the linear logistic test stated that community characteristics and patient satisfaction affect simultaneously or jointly on the utilization of outpatient health services in Kertha Usada Hospital, Singaraja.

\section{REFERENCES}

Cheruvu, V.K. \& Oancea, S.C., (2016). Current depression as a potential barrier to health care utilization in adult cancer survivors. The International Journal of Cancer Epidemiology, Detection, and Prevention, 132-137, p.44.

Deitelzweig Steven; Laliberte Francois; Crivera Concetta; Germain Guillaume; Bookhart Brahim; Olson William; Schein Jeffrey; Lefebvre Patrick, 2016. Hospitalizations and Other Health Care Resource Utilization Among Patients with Deep Vein Thrombosis Treated with Rivaroxaban Versus Low-molecular-weight Heparin and Warfarin in the Outpatient Setting. Elsevier HS Journals.

Ditto , P. \& Moore, K., 2015. Ditto, P and Moore, K 2015, Beliefs about Physicians: Their Role In Hearth Care Utilization , Satisfaction, and Compliance. Dapertment of Psychologi,. Dapertment of Psychologi, .

Eriksson, H., Marie, I., Berrum, B. \& Morck, I., 2011. Reducing queues: demand and capacity variations. International Journal of Health Care Quality Assurance, 24, pp.592-600.

Hermawan, A., Aminoto, C. \& Septiwi, C., 2011. Jurnal Ilmiah Kesehatan Keperawatan. Analisis Faktor Yang Berhubungan Dengan Masyarakat berobat di Puskesmas Kecamatan Buayan, 7.

Muriithi, M.K., (2013). The Determinants Of Health-Seeking Behavior In A Nairobi Slum, Kenya. European Scientific Journal, 9, p.8.

Muninjaya, Gde AA, 2011, Manajemen Mutu Pelayanan Kesehatan, Jakarta, EGC. 
Napirah, M.R., Rahman, A. \& Tony, A., 2016. Faktor-faktor yang berhubungan dengan Pemanfaatan Pelayanan Kesehatan di Wilayah Kerja Puskesmas Tambarana Kecamatan Posos Pesisir Utara Kabupaten Poso, 4, pp.29-39.

Nitisusastro. (2012).Perilaku Konsumen Dalam Perspektif Kewirausahaan. Bandung : Alfabeta.

Notoadmojo, S. 2012. Promosi Kesehatan dan Perilaku Kesehatan. Jakarta : PT Rineka Cipta

Rumengan, D. S. S., Umboh , J. M. L., Kandou, G. D. 2015. Faktor - Faktor Yang Berhubungan Dengan Pemanfaatan Pelayanan Kesehatan Pada Peserta BPJS Kesehatan Di Puskesmas Paniki Bawah Kecamatan Mapanget Kota Manado. Surakarta : Universitas Sam Ratulangi Manado.

Sholihah, Q., dan Kuncoro, W., 2014. Keselamatan Keselamatan Kerja. Penerbit Kedokteran (EGC). Jakarta.

Supriani, D. Faktor yang Berhubungan dengan Pemanfaatan Pelayanan Kesehatan Gigi dan Mulut di Poliklinik Gigi RSUD Kabupaten Badung 2013

Suryati. 2009. Cut Meutia di Kota Lhokseumawe. Majalah Kedokteran Nisantara. Vol 42 Hal 41-47.

Su`udi, A., 2010. Analisis Pemanfaatan Jaminan Kesehatan. Tesis FKM UI. Depok. 